\title{
Using ClassDojo to motivate kids participation in the English as Foreign Language online classes during the Covid-19 pandemic: a case study
}

\section{Usando ClassDojo para motivar a participação de crianças nas aulas online de inglês durante a pandemia do Covid-19: um estudo de caso}

\author{
Jardel Coutinho dos Santos ${ }^{1}$, Mayra Carolina Vélez Ruiz ${ }^{2}$ \\ ${ }^{1}$ Universidad Técnica Estatal de Quevedo, Quevedo, Equador. ORCID: https://orcid.org/0000-0002-8626-7229 \\ 2 Universidad Técnica Estatal de Quevedo, Quevedo, Equador. ORCID: https://orcid.org/0000-0003-4407-2965
}

Mail to/Autor para correspondência/Correo a: Mayra Carolina Vélez Ruiz, mayracarolinavelez@gmail.com

Submitted/Recibido: 30 de dezembro de 2020; Approved/Aceptado: 09 de março de 2021

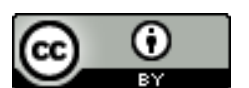
Copyright (C) 2021 Santos \& Vélez Ruiz. All journal content (including directions, editorial policy and templates) is under a Creative Commons license Attribu-
tion 4.0 International. By being published by this journal, articles are free to use in educational, research and non commercial environments, with mandatory
attribution of authorship. To further information check http://revistas.ufpr.br/atoz/about/submissions\#copyrightNotice.

\begin{abstract}
Introduction: COVID-19 pandemic has changed the way the classes were conducted worldwide. Ecuadorian teachers were required to implement synchronously and asynchronously classes. Consequently, all the content was adapted to this new type of class. On the other hand, students have presented tiredness during classes, demotivation to learn, and unhappiness with this new modality. Studies have demonstrated the advantages of Computer Assisted Language Learning (CALL) to motivate learners. Method: This case study aimed to investigate the efficiency of ClassDojo to motivate Ecuadorian students' participation during the English online classes. A sample of 29 sixth-graders from a private school, ranging from 9 to 11 years old, participated in this research. The data were collected during four months of classes (August to November 2020) through tests (pre and post), interview, and teacher's journal. Results: After the implementation of the app, the participants presented a significant difference between the pre-test $(M=2.03, S D=1.26)$ and post-test $(M=7.28, S D=1.69)$ with a $p=0.00$ and Cohen's $\mathrm{d}=3.52$. The results gathered from the pre and post-test revealed that ClassDojo motivated students' participation in class. Results from the interview showed students' positive opinions on the use of ClassDojo. Conclusions: This app allowed participants to learn, interact, and have fun at the same time. This research is addressed to teachers who have online classes and want to increase learners' participation.
\end{abstract}

Keywords: ClassDojo; Class participation; Motivation; Online classes; COVID-19.

\begin{abstract}
Resumo
Introdução: A pandemia da COVID-19 mudou a forma como as aulas eram ministradas em todo o mundo. Os professores equatorianos foram obrigados a implementar aulas de forma síncrona e assíncrona. Consequentemente, todo o conteúdo foi adaptado para este novo tipo de aula. Por outro lado, os alunos, apresentam cansaço durante as aulas, desmotivação para aprender e infelicidade com a nova modalidade. Estudos têm demonstrado as vantagens do Computer Assisted Language Learning (CALL) para motivar os alunos. Método: Este estudo de caso teve como objetivo investigar a eficiência do ClassDojo para motivar a participação de alunos equatorianos durante as aulas online de inglês. Uma amostra de 29 alunos do sexto ano de uma escola particular, com idades entre 9 e 11 anos, participou desta pesquisa. Os dados foram coletados durante quatro meses de aulas (agosto a novembro de 2020) por meio de provas (pré e pós), entrevista e diário do professor. Resultados: Após a implementação do aplicativo, os participantes apresentaram diferença significativa entre o pré-teste $(M=2,03, D P=1,26)$ e o pós-teste $(M=7,28, D P=1,69)$ com $p=0,00$ e d de Cohen $=3,52$. Os resultados recolhidos do pré e pós-teste revelaram que o ClassDojo motivou a participação dos alunos nas aulas. Os resultados da entrevista mostraram as opiniões positivas dos alunos sobre o uso do ClassDojo. Conclusões: Este aplicativo permitiu aos participantes aprender, interagir e se divertir ao mesmo tempo. Esta pesquisa é dirigida a professores que têm aulas online e desejam aumentar a participação dos alunos.
\end{abstract}

Palavras-chave: ClassDojo; Participação nas aulas; Motivação; Aulas online; COVID-19.

\section{INTRODUCTION}

COVID-19 pandemic has changed the way the classes were conducted worldwide. Everyone needed to (re)adapt to the new modality of classes (Muthuprasad, Aiswarya, Aditya, \& Jha, 2020) since it is the first time some countries would have this online method. Ecuador has never had online classes in the elementary and high school contexts before. This new type has been a challenge for all teachers and students (Cáceres-Piñaloza, 2020), but it was a necessary step for education (Bao, 2020; Halim, Hashim, and Yunus, 2020).

Ecuadorian teachers were required to implement synchronously and asynchronously classes. Consequently, all the content was adapted to this new type of class. On the other hand, students have presented tiredness during class, demotivation to learn, and unhappiness with this new modality. As a consequence, in some situations, they were not participating actively. Researches said that learners learn better when they have active class participation (Auster and MacRone, 1994; McKinney and Graham-Buxton, 1993; Weisz, 1990). Studies have proved that motivation during online classes is a critical determining factor of spontaneous participation and fulfillment of each student (Bolliger, Supanakorn, and Boggs, 2010; Hsu, Wang, and Levesque-Bristol, 2019). For 
this reason, educators have encountered themselves in a dilemma: how to motivate and assess participation in online contexts (Precourt \& Gainor, 2018).

Luckily, there are various educational technology tools available to teachers to deal with the given-classes challenges imposed by the COVID-19 pandemic (Rodrigues, Almeida, Figueiredo, \& Lopes, 2019). Furthermore, some tools can be used to assess remotely or motivate learners during this new process. Studies have demonstrated the advantages of Computer Assisted Language Learning (CALL) to motivate learners. Daniels (2004) conducted a study with fifth-grade students and used the "Power Writing" program to motivate them to write. The results obtained showed a breakthrough in their motivation. Another way teachers can foster students' participation and, at the same time, motivate them to learn is using gamification. Games proved their "remarkable motivational power" (Dicheva, Dichev, Agre, \& Angelova, 2015, p. 75).

ClassDojo is an excellent app that meets the parameters of gamification. It fosters students' positive behavior and gives positive reinforcement to them. Thus, the present study investigates the efficiency of ClassDojo to motivate sixth-graders Ecuadorian students' participation during the online classes. The results will be significant for teachers to know efficient strategies to be used in class to promote active learning through active class participation. Two research questions were addressed to be answered by the end of this study: 1) to what extent has ClassDojo motivated kids' participation in the EFL online classes? And 2) what are students' opinions on using ClassDojo in online classes?

\section{CLASSROOM PARTICIPATION}

For decades, classroom participation has received researchers' attention (Crawford and MacLeod, 1990; Heller, Puff, and Mills, 1985). The reason why this phenomenon happens is that students have better learning results when they actively participate in the classroom (Auster MacRone, 1994), and "oral skills can (not) be recognized without class participation being assessed" (Armstrong \& Boud, 1983, p. 35). However, there is a difference in opinions between some educators. Some believe that assessing participation motivates learners (Lyons, 1989) and can show students' priorities (Bean \& Peterson, 1998). On the other hand, some believe that class participation should be voluntary (Lowman and Lowman, 1995; Tiberius, 1990), and for that reason should not be graded.

Classroom participation is defined as "the number of unsolicited responses volunteered" (Burchfield \& Sappington, 1999, p. 290). Some factors influence students participation, such as those cited by Weaver and Qi (2005): a) class size and opportunity, many students per class hinder opportunities to participate; b) Faculty as the authority of knowledge, hierarchical power of the class, commonly called by Freire (1970) as the "banking model," in other words, teachers have the prominent active voice and students are passive learners, just absorbing information; and finally, c) fear of professor criticism, the role of negative emotions in class.

Then, considering all the discussion above, the method used in this research to assess participation is based on a study conducted by Precourt Gainor (2018). The rubric used focused on the combination of two components: participation frequency and participation consistency.

\section{ONLINE CLASSES DURING COVID-19 PANDEMIC}

During the covid-19 pandemic, the online classes in Ecuador were divided into two parts by many schools: synchronous with online interaction mediated by a technological tool such as Zoom or Google meets, and asynchronous, independent learning using an online platform according to each context.

This modality of learning requires more preparation for the professor/instructor because some situations can affect learning. Ku, Tseng, and Akarasriworn (2013) said that interaction is one element that influences students' outcomes and motivation. The lack of face-to-face classes might decrease the number of interactions between student-teachers and students-students (Saghafi, Franz, \& Crowther, 2014). For that reason, educators have an important role. They are responsible for fostering discussion among learners (Jones, 2006). One crucial way is through the correct choice of technological tools (Michael, Maithya, Cheloti, et al., 2016). A satisfied student is a synonym for successful learning (Marks, Sibley, \& Arbaugh, 2005).

\section{MOTIVATION}

Working with students' motivation is essential because it "energizes" human behavior and "gives it direction" (Dornyei \& Ottó, 1998, p. 117). In the L2 classes, motivation plays an important role (Gardner, 1985; Gardner, Masgoret, Tennant, and Mihic, 2004; Lightbown and Spada, 1993) because it can influence students' learning. Motivation impulses people to reach their goals (Harmon-Jones, Harmon-Jones, \& Price, 2013) and makes students learn and participate (Cole, Feild, \& Harris, 2004).

During the online class environment, students can decrease their motivation to learn (Inoue, 2007). The lack of face-to-face interaction, body contact, and facial expression are elements that might cause this demotivation 
(Alqurashi, 2019; Sebastianelli, Swift, and Tamimi, 2015). Consequently, a more motivated student will be more successful in the online class than a less motivated student (Hsu et al., 2019; Nelson, Oden, and Williams, 2019). This circumstance happens because "the learning environment also influences human motivation" (Baber, 2020, p. 287). A study conducted by Adams, Randall, and Traustadóttir (2015) found out that online students presented less positive learning outcomes, affected by a lack of motivation than face-to-face students.

\section{GAMIFICATION}

Gamification is a term that appeared in 2008 (Deterding, Dixon, Khaled, \& Nacke, 2011) but gained attention after the second half of 2010 (Dicheva et al., 2015). Its primary purpose is to motivate students to learn (Domínguez et al., 2013), but also it focuses on engagement, participation, and enjoyment (Nah, Zeng, Telaprolu, Ayyappa, \& Eschenbrenner, 2014). The word gamification means "the use of game elements, game design and game dynamics in non-game contexts" (Lin, 2014). In other words, it is to get elements/characteristics belonging to video games and apply them in different contexts such as education or marketing.

Brewer et al. (2013) researched gamification's efficiency in motivating children through a prize system. They noticed the participants became more motivated in task completions by increasing $73 \%$ to $97 \%$. On the other hand, Barata, Gama, Jorge, and Gonçalves (2013) used game elements like experience points, levels, leaderboards, challenges, and badges to motivate an Information Systems and Computer Engineering course participation during the classes. The results showed an improvement in students' engagement, but their grades were not significantly different.

\section{CLASSDOJO}

ClassDojo is a classroom management web-based system that works with gamification. This app awards students with virtual points when they perform positive behavior during the class. First, teachers set up a class. Second, they enroll all of their students in this class. Third, the app automatically gives the students an avatar. However, each learner can customize their avatar and choose the one that best describes them. Finally, the app is ready to be used. Figure 1 shows one class example provided by the app.

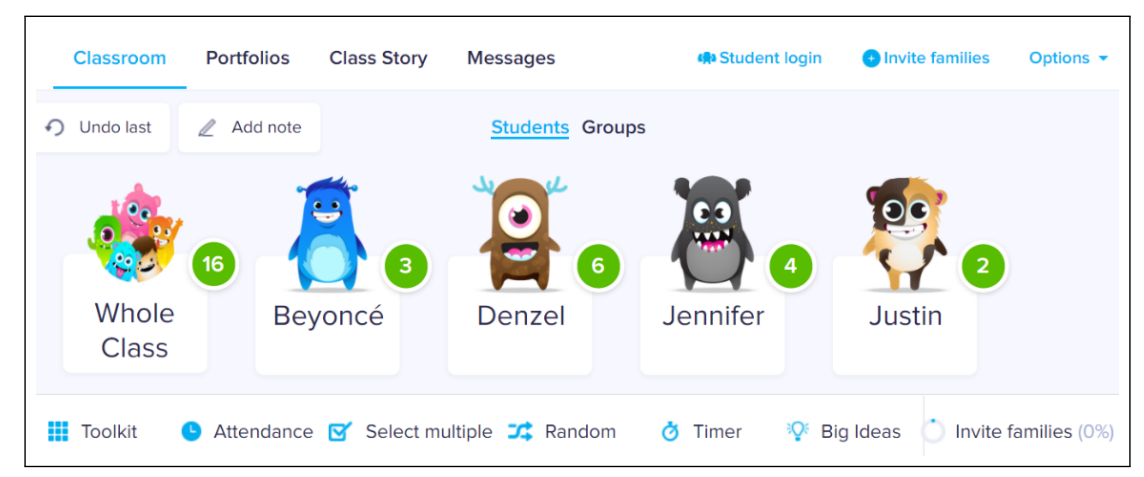

Figure 1. ClassDojo Example.

Source: ClassDojo website.

The use of ClassDojo in education has grown lately (Cetin and Cetin, 2018; Krach, McCreery, and Rimel, 2017). More than 35 million teachers, parents, and students have used this app for educational purposes (Friedemann, Baumbach, \& Jantke, 2015). Maclean-Blevins and Muilenburg (2013) researched the efficiency of ClassDojo on teacher praise for student behavior. By the end of the study, they concluded that students increased positive behavior and decreased negative behaviors. Lin (2014) used Classdojo and another app to assess classroom participation and performance. She found out that students were comfortable beeing assessed using both gamification apps and were motivated to participate more. Almost all of the studies focused on using ClassDojo to enhance positive behavior in class, a few works with ClassDojo and spark classroom participation, and almost none of them worked with ClassDojo and online classes.

\section{METHODOLOGY}

This research is a case study with a mixed-method approach (qualitative and quantitative) whose focus is sixth-graders English learners. This type of research "facilitates exploration of a phenomenon within its context, using a variety of data sources" (Baxter, Jack, et al., 2008, p. 544).

Setting and Participants 
This study was carried out in a private school in Los Ríos Province, Ecuador, during the English classes. The participants are 29 sixth-graders with ages from 9 to 11 years old. Among the participants, 16 were female, and 13 were male. They all pursue the A2 level of English according to the CEFR.

It is the first time this school offers this new modality of class; therefore, first-time students have online classes. Since June 2020, due to the covid-19 pandemic, the participants were offered two class types, synchronous, online interactions twice a week using the Zoom platform and asynchronous activities three times a week using their school learning platform. Table 1 shows the topics worked during each week and the classes where Class Dojo was used.

\begin{tabular}{|c|c|c|c|}
\hline Week & Topic & Asynchronous & ***Synchronous \\
\hline August 3th - August 9th* & Verb to $\mathrm{Be}$ & 3 classes & 2 classes \\
\hline August 10th - August 16th & Simple Present & 3 classes & 2 classes \\
\hline August 17th - August 22th & Adverb of Frequency & 3 classes & 2 classes \\
\hline August 24th - August 30th & Daily routine & 3 classes & 2 classes \\
\hline August 31st - September 6th & Going to & 3 classes & 2 classes \\
\hline September 7th - September 13th & Will & 3 classes & 2 classes \\
\hline September 14th - September 20th & Should & 3 classes & 2 classes \\
\hline September 21st - September 27th & Must & 3 classes & 2 classes \\
\hline September 28th - October 4th & First Conditional & 3 classes & 2 classes \\
\hline October 5th - October 11th & Exam Week & . & . \\
\hline October 12th - October 18th & Vacation week & - & - \\
\hline October 19th - October 25th & Used to & 3 classes & 2 classes \\
\hline October 26th - November 1st & Comparative & 3 classes & 2 classes \\
\hline November 2nd - November 8th & Superlative & 3 classes & 2 classes \\
\hline November 9th - November 15th & Comparative $x$ Superlative & 3 classes & 2 classes \\
\hline November 16th - November 22nd & Preposition of place & 3 classes & 2 classes \\
\hline November 23rd - November 29th** & Countable $\times$ Uncountable nouns & 3 classes & 2 classes \\
\hline 17 weeks & 15 topics & 45 classes & 30 classes \\
\hline
\end{tabular}

Table 1. Classes Schedule.

\section{Data collection and analysis}

The data was collected throughout four months of classes (from August to November 2020). Three instruments were designed to answer the research questions, make the data triangulation, and ensure validity and reliability.

First, one rubric was used in each class in order to measure each student's participation. The grades from the first day and the last day were utilized as a pre and post-test. The analyses were made using the statistics software SPSS 25. It was calculated the p-value (Gehlbach \& Robinson, 2018)) and Cohen's d (Thalheimer \& Cook, 2002).

Second, students' interviews. With ten minutes-length, an interview was done with all the participants to know their opinions about using ClassDojo in class. An analysis based on Holliday (2005) was done to categorize the data. Finally, a teaching journal. Every class, the research kept a journal with notes and observations about the class. It is essential to highlight that this research followed ethical procedures. The consent letter was sent to the parents and the school. Only voluntary students participated in this study. Table 2 demonstrates that when each instrument was applied and what its goals are.

\begin{tabular}{|c|c|c|}
\hline \multicolumn{3}{|c|}{ Data Collection } \\
\hline Instruments & Goal & Date \\
\hline Rubric* & Assess student's participation & From August 4th to November 28th \\
\hline & Become acquainted with the participants' & \\
\hline Interview & $\begin{array}{l}\text { opinions on the use of Class Dojo in the } \\
\text { class }\end{array}$ & December 1st, 2020 \\
\hline Teacher's journal* & $\begin{array}{l}\text { Write reflections, observations, and insights } \\
\text { about the class, the participants, and the } \\
\text { research process }\end{array}$ & From August 4th to November 28th \\
\hline
\end{tabular}

Table 2. Data Collection Instruments. 


\section{RESULTS AND DISCUSSION}

Quantitative results

To answer the first research question, the authors ran a paired t-test in the SPSS 25 to compare the pre and post-test results. Table 3 shows that the participants had a significant difference between pre-test $(\mathrm{M}=2.03$, $\mathrm{SD}=1.26)$ and post-test $(\mathrm{M}=7.28, \mathrm{SD}=1.69)$ scores when examining all the samples together; $\mathrm{t}(28)=-25.87$.

The $\mathrm{p}$-value $(\mathrm{p}=0.00)$ is less than 0.05 , which shows a high level of significance (Gehlbach \& Robinson, 2018). The alpha value $(\mathrm{d}=3.52)$, more significant than 0.08 , supports the idea of using gamification through ClassDojo to motivate students to participate more in online classes. One hypothesis is because "there were more and better-rewarded challenges, and these gave students more opportunities to succeed" (Barata et al., 2013, p. 16).

\begin{tabular}{lcccc}
\hline \multicolumn{5}{c}{$(\mathbf{N}=\mathbf{2 9})$} \\
\hline Test & $\mathbf{M}$ & SD & Sig. $(\mathbf{P})$ & Es \\
\hline Pre & 2.03 & 1.26 & 0.000 & 3.52 \\
\hline Post & 7.28 & 1.69 & & \\
\hline Note: & N= sample $M=$ mean \\
Sd= standard deviation Sig (P): \\
Significance Es= effect size \\
(Cohen's d)
\end{tabular}

Table 3. Paired Sample t-test Results from Pre and Post-test.

During the pre-test, the minimum grade was one, and the maximum was four, which shows that students lacked class participation. However, in the post-test, the minimum grade was four, and the maximum was ten, suggesting that students increased their class participation during the four months of classes. Figure 2 display these grades.

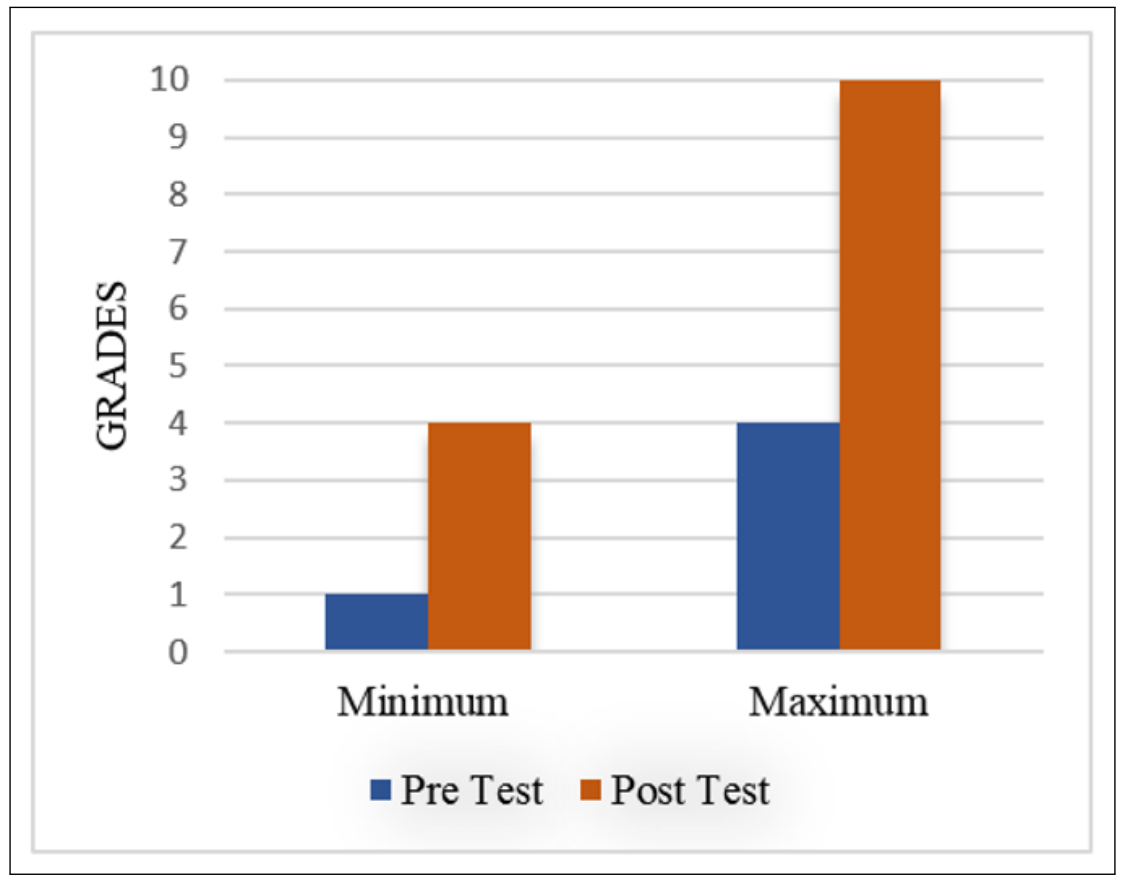

Figure 2. Minimum and Maximum grade from pre/post-test.

The graphic above showed that some students are still not participating actively after the implementation. The minimum grade is 4 , which is still not high. The authors expected a higher minimum grade. Nevertheless, this number of students is less than those who had more than five in their grades. Students' perspectives on using ClassDojo

To answer the second research question, by the end of the four months using ClassDojo, an interview was carried out to gather qualitative participants' feedback on the use of the app. The twenty-nine students reported that they all liked to use ClassDojo. The participants mentioned many reasons that made this app successful in classes. Some learners said that when realizing they had many points, they comprehended they were improving actively in the class: "I like it because it gives you points, and I like that because you feel that you are improving." 
(Participant 1, interview, December 1st, 2020) and "Because I can see how much I participate in the class and if I am okay." (Participant 2, interview, December 1st, 2020).

The points in the ClassDojo helped students see their advances in learning. If they had fewer points than their classmates, they made the self-assessment and understood that they were not participating. The healthy competition provided by the app, together with positive reinforcement, made students increase their participation (Barata et al., 2013).

Another opinion that came out was regarding the benefits of ClassDojo to promote interaction among students. Students at the beginning of the class did not interact with their classmates because everything was done online. They just saw their classmates in small boxes due to the Zoom platform. So, this hindered students' interactions (Saghafi et al., 2014). In one of the utterances from the teachers' journal, it is possible to understand this situation:

Students seem demotivated to learn. They are not the same as I used to know them. It looks like they are just in the class because they have to. They used to be active learners. Maybe sitting in a chair all day and do not have face-to-face interactions with their classmates during class, especially during the break time, has made them feel sad. (Researcher's journal, July 16th, 2020).

Some students confirmed this idea when they stated that one of the reasons they liked to use the app was because they could interact with their classmates; "I like using ClassDojo because we all interact, and I missed that" (Participant 3, interview, December 1st, 2020), and "ClassDojo has helped me interact more with my classmates. This made me feel pleased" (Participant 4, interview, December 1st, 2020. The interaction was an essential factor in motivating students to participate. When students started to interact more, they became more motivated to learn (Mercer \& Howe, 2012).

Finally, ClassDojo provided enjoyment during the class. The app was able to conciliate learning with entertainment. Bisson and Luckner (1996) claimed that "fun can motivate learners to engage themselves in activities with which they have little or no previous experience" (p.110). The concept of having fun is directly related to intrinsic motivation (Dattilo, Kleiber, et al., 1993; Middleton, Littlefield, and Lehrer, 1992). Thus, having fun was a factor that motivated students' participation. The following utterances confirm this idea: "I like ClassDojo because students have fun while learning" (Participant 5, interview, December 1st, 2020) and "Having fun in class through ClassDojo made me want to participate" (Participant 6, interview, December 1st, 2020) Through the quotes, the participants reported that the app motivates them to participate and to have fun. Cetin and Cetin (2018) obtained the same results in their study when they researched middle school students' perspectives on the use of ClassDojo.

\section{CONCLUSION}

2020 has demonstrated to be an atypical year for all the areas in society. Some have suffered more with the consequences of the pandemic than others. The educational field has shown that, even in dire circumstances, educators were able to remedy the situation and provide the best for their students. Some teachers have encountered some problems like lack of motivation and tiredness to foster participation, but these factors did not make them give up on providing the best education for their students. Teachers showed that they have the ability to (re)adapt in all situations.

Students had their class performance affected somehow during the covid-19 pandemic, maybe because they were not used to this new online modality of class or the pressure of been locked up at home. Learners decreased their motivation to learn, and, as a result, they did not participate actively in class as they were used to do. For this reason, this study showed the importance of teacher searching for active methodologies to be used with their students.

Working with gamification has displayed in some researches good results for education. ClassDojo proved, according to the data, that it can motivate kids' participation in the online classes, foster healthy competitiveness among classmates, and enhance learning and enjoyment. The findings showed that students were able to learn, interact, and have fun at the same time. 


\section{REFERENCES}

Adams, A. E., Randall, S., \& Traustadóttir, T. (2015). A tale of two sections: An experiment to compare the effectiveness of a hybrid versus a traditional lecture format in introductory microbiology. CBE-Life Sciences Education, 14(1), 1-8. doi: https://doi.org/10.1187/cbe.14-08-0118

Alqurashi, E. (2019). Predicting student satisfaction and perceived learning within online learning environments. Distance Education, 40(1), 133-148. doi: https://doi.org/10.1080/01587919.2018.1553562

Armstrong, M., \& Boud, D. (1983). Assessing participation in discussion: An exploration of the issues. Studies in Higher Education, 8(1), 33-44. doi: https://doi.org/10.1080/03075078312331379101

Auster, C. J., \& MacRone, M. (1994). The classroom as a negotiated social setting: An empirical study of the effects of faculty members' behavior on students' participation. Teaching sociology, 22, 289-300. doi: https://doi.org/10.2307/1318921

Baber, H. (2020). Determinants of students' perceived learning outcome and satisfaction in online learning during the pandemic of covid-19. Journal of Education and ELearning Research, 7(3), 285-292. Retrieved from https:// ssrn.com/abstract $=3679489$

Bao, W. (2020). Covid-19 and online teaching in higher education: A case study of peking university. Human Behavior and Emerging Technologies, 2(2), 113-115. Retrieved from https://doi.org/10.1002/hbe2.191

Barata, G., Gama, S., Jorge, J., \& Gonçalves, D. (2013). Improving participation and learning with gamification. In Proceedings of the first international conference on gameful design, research, and applications (pp. 10-17). ACM.

Baxter, P., Jack, S., et al. (2008). Qualitative case study methodology: Study design and implementation for novice researchers. The qualitative report, 13(4), 544-559. Retrieved from http://www.nova.edu/ssss/QR/QR13-4/ baxter.pdf

Bean, J. C., \& Peterson, D. (1998). Grading classroom participation. New directions for teaching and learning, 1998(74), 33-40. Retrieved from https://doi.org/10.1002/ tl. 7403

Bisson, C., \& Luckner, J. (1996). Fun in learning: The pedagogical role of fun in adventure education. Journal of Experiential Education, 19(2), 108-112. Retrieved from https://doi.org/10.1177/105382599601900208

Bolliger, D. U., Supanakorn, S., \& Boggs, C. (2010). Impact of podcasting on student motivation in the online learning environment. Computers $\&$ Education, 55(2), 714-722. doi: https://doi.org/10.1016/j.compedu.2010.03.004

Brewer, R., Anthony, L., Brown, Q., Irwin, G., Nias, J., \& Tate, B. (2013). Using gamification to motivate children to complete empirical studies in lab environments. In Proceedings of the 12th international conference on interaction design and children (pp. 388-391).

Burchfield, C. M., \& Sappington, J. (1999). Participation in classroom discussion. Teaching of Psychology, 26 (4).

Cáceres-Piñaloza, K. F. (2020). Educación virtual: Creando espacios afectivos, de convivencia y aprendizaje en tiempos de covid-19. CienciAmérica, 9(2), 38-44. doi: https://doi:10.33210/ca.v9i2.284

Cetin, H., \& Cetin, I. (2018). Views of mid- dle school students about class dojo education technology. Acta Didactica Napocensia, 11(3/4), 89-96. doi: https://doi.org/10.24193/adn.11.3-4.7

Cole, M. S., Feild, H. S., \& Harris, S. G. (2004). Student learning motivation and psychological hardiness: Interactive effects on students' reactions to a management class. Academy of Management Learning \&5 Education, 3(1), 64-85. doi: https://doi.org/10.5465/amle.2004.12436819

Crawford, M., \& MacLeod, M. (1990). Gender in the college classroom: An assessment of the "chilly climate" for women. Sex Roles, 23(3-4), 101-122. doi: https://doi.org/10.1007/BF00289859

Daniels, A. (2004). Composition instruction: Using technology to motivate students to write. Information Technology in Childhood Education Annual, 2004(1), 157-177. doi: https://www.learntechlib.org/primary/p/12898/

Dattilo, J., Kleiber, D., et al. (1993). Psychological perspectives for therapeutic recreation research: the psychology of enjoyment. Research in therapeutic recreation: concepts and methods., 57-76.

Deterding, S., Dixon, D., Khaled, R., \& Nacke, L. (2011) From game design elements to gamefulness: defining" gamification". In Proceedings of the 15th international academic mindtrek conference: Envisioning future media environments (pp. 9-15).

Dicheva, D., Dichev, C., Agre, G., \& Angelova, G. (2015). Gamification in education: A systematic mapping study. Journal of Educational Technology \& Society, 18(3), 75-88. Retrieved from www.jstor.org/stable/jeductechsoci.18.3.75

Domínguez, A., Saenz-de Navarrete, J., De-Marcos, L., Fernández-Sanz, L., Pagés, C., \& Martínez-Herráiz, J.-J. (2013). Gamifying learning experiences: Practical implications and outcomes. Computers \& education, 63, 380-392. doi: https://doi.org/10.1016/j.compedu.2012.12.020

Dornyei, Z., \& Ottó, I. (1998). Motivation in action: A process model of 12 motivation. In (pp. 43-69). Retrieved from http://eprints.nottingham.ac.uk/id/eprint/39

Friedemann, S., Baumbach, L., \& Jantke, K. P. (2015). Textbook gamification. In Proceedings of the "th international conference on computer supported education-volume 2 (pp. 116-126). doi: https://doi.org/10.5220/0005489101160126

Gardner, R. C. (1985). Social psychology and second language learning: The role of attitudes and motivation. London: Arnold.

Gardner, R. C., Masgoret, A.-M., Tennant, J., \& Mihic, L. (2004). Integrative motivation: Changes during a year-long intermediate-level language course. Language learning, 54(1), 1-34. doi: https://doi.org/10.1111/j.14679922.2004.00247.x

Gehlbach, H., \& Robinson, C. D. (2018). Mitigating illusory results through preregistration in education. Journal of Research on Educational Effectiveness, 11(2), 296-315. doi: https://doi.org/10.1080/19345747.2017.1387950

Halim, M. S. A. A., Hashim, H., \& Yunus, M. M. (2020). Pupils' motivation and perceptions on esl lessons through online quiz-games. Journal of Education and E-Learning Research, 7(3), 229-234. doi: https://doi.org/10.20448/journal.509.2020.73.229.234

Harmon-Jones, E., Harmon-Jones, C., \& Price, T. F. (2013). What is approach motivation? Emotion Review, 5(3), 291-295. doi: https://doi.org/10.1177/1754073913477509

Heller, J. F., Puff, C. R., \& Mills, C. J. (1985). As- 
sessment of the chilly college climate for women. The Journal of Higher Education, 56(4), 446-461. doi: https://doi.org/10.2307/1981305

Holliday, A. (2005). Doing \& writing qualitative research. London: Sage Publications.

Hsu, H.-C. K., Wang, C. V., \& Levesque-Bristol, C. (2019). Reexamining the impact of self-determination theory on learning outcomes in the online learning environment. Education and Information Technologies, 24(3), 2159-2174. doi: https://doi.org/10.1007/s10639-019-09863-w

Inoue, Y. (2007). Online education for lifelong learning: a silent revolution. In Online education for lifelong learning (pp. 1-27). IGI Global.

Jones, S. (2006). Evaluation of instructor knowledge on structuring and facilitating effective online discourse. The Journal of Educators Online, 3(2), 1-14. doi: https://doi.org/10.9743/jeo.2006.2.1

Krach, S. K., McCreery, M. P., \& Rimel, H. (2017). Examining teachers' behavioral management charts: A comparison of class dojo and paper-pencil methods. Contemporary School Psychology, 21(3), 267-275. doi: https://doi.org/10.1007/s40688-016-0111-0

Ku, H.-Y., Tseng, H. W., \& Akarasriworn, C. (2013). Collaboration factors, teamwork satisfaction, and student attitudes toward online collaborative learning. Computers in human Behavior, 29(3), 922-929. doi: https://doi.org/10.1016/j.chb.2012.12.019

Lightbown, P. M., \& Spada, N. (1993). How languages are learned. Oxford university press.

Lin, N. (2014). Assessing classroom participation and performance through gamification systems in foreign language classrooms. In Society for information technology $\mathbb{E}$ teacher education international conference (pp. 1772-1777). Retrieved from https://www.learntechlib.org/primary/p/ 131031

Lowman, J., \& Lowman, J. (1995). Mastering the techniques of teaching. Jossey-Bass.

Lyons, P. R. (1989). Assessing classroom participation. College Teaching, 37(1), 36-38. doi: https://doi.org/10.1080/87567555.1989.10532154

Maclean-Blevins, A., \& Muilenburg, L. (2013). Using class dojo to support student self-regulation. In Edmedia + innovate learning (pp. 1684-1689). Retrieved from https:// www.learntechlib.org/primary/p/112192/

Marks, R. B., Sibley, S. D., \& Arbaugh, J. B. (2005). A structural equation model of predictors for effective online learning. Journal of management education, 29(4), 531-563. doi: https://doi.org/10.1177/1052562904271199

McKinney, K., \& Graham-Buxton, M. (1993). The use of collaborative learning groups in the large class: Is it possible? Teaching Sociology, 21(4), 403-408. doi: https://doi.org/10.2307/1319092

Mercer, N., \& Howe, C. (2012). Explaining the dialogic processes of teaching and learning: The value and potential of sociocultural theory. Learning, culture and social interaction, 1(1), 12-21. doi: https://doi.org/10.1016/j.lcsi.2012.03.001

Michael, F. M., Maithya, R., Cheloti, S. K., et al. (2016). Influence of teacher competency on integration of ict in teaching and learning in public secondary schools in machakos. Journal of Education and E-learning Research, 3(4), 143-149. doi: https://doi.org/10.20448/journal.509/2016.3.4/509.4.143.149
Middleton, J. A., Littlefield, J., \& Lehrer, R. (1992). Gifted students' conceptions of academic fun: An examination of a critical construct for gifted education. Gifted Child Quarterly, 36(1), 38-44. doi: https://doi.org/10.1177/001698629203600109

Muthuprasad, T., Aiswarya, S., Aditya, K., \& Jha, G. K. (2020). Students' perception and preference for online education in india during covid-19 pandemic. Social Sciences \& Humanities Open, 3(1), 1-38. doi: http://dx.doi.org/10.2139/ssrn.3596056

Nah, F. F.-H., Zeng, Q., Telaprolu, V. R., Ayyappa, A. P., \& Eschenbrenner, B. (2014). Gamification of education: a review of literature. In International conference on hci in business (pp. 401-409). doi: http://dx.doi.org/10.1007/9783-319-07293-7_39

Nelson, M. L., Oden, K. L., \& Williams, L. L. (2019). Student motivation to participate in asynchronous on-line discussions. , 9(9), 6-11.

Precourt, E., \& Gainor, M. (2018). Factors affecting classroom participation and how participation leads to a better learning. Accounting Education, 28(1), 100-118. doi: https://doi.org/10.1080/09639284.2018.1505530

Rodrigues, H., Almeida, F., Figueiredo, V., \& Lopes, S. L. (2019). Tracking e-learning through published papers: A systematic review. Computers \& Education, 136, 87-98. doi: https://doi.org/10.1016/j.compedu.2019.03.007

Saghafi, M. R., Franz, J., \& Crowther, P. (2014). An integrated blended model for the contemporary learning environments. Journal of Interactive Learning Research, 25(4), 531-549. Retrieved from https://www.learntechlib .org/primary/p/40402/

Sebastianelli, R., Swift, C., \& Tamimi, N. (2015). Factors affecting perceived learning, satisfaction, and quality in the online mba: A structural equation modeling approach. Journal of Education for Business, 90(6), 296-305. doi: https://doi.org/10.1080/08832323.2015.1038979

Thalheimer, W., \& Cook, S. (2002). How to calculate effect sizes from published research: A simplified methodology. Work-Learning Research, 1, 1-9. Retrieved from www.work -learning.com

Tiberius, R. G. (1990). Small group teaching: A troubleshooting guide. Ontario Institute for Studies in Education Press.

Weaver, R. R., \& Qi, J. (2005). Classroom organization and participation: College students' perceptions. The Journal of Higher Education, 76(5), 570-601. Retrieved from http:// www.jstor.org/stable/3838840

Weisz, E. (1990). Energizing the classroom. College Teaching, 38(2), 74-76. Retrieved from https://www.jstor.org/ stable/ 27558400

How to cite this article (APA):

Santos, J. C. \& Vélez Ruiz, M. C. (2021). Using ClassDojo to motivate kids participation in the English as Foreign Language online classes during the Covid-19 pandemic: a case study. AtoZ: novas práticas em informação e conhecimento, 10(2), 58 - 65 . Retrieved from: http://dx.doi.org/10.5380/ atoz.v10i2.78711 